\title{
Solutions to an alien species invasion from aquarium aquaculture: Isolation and characterization of acid soluble collagen from sailfin catfish, Pterygoplichthys disjuctivus (Weber, 1991) in Sri Lanka
}

\author{
H.M.G.K. Herath ${ }^{1}$, Nishantha K. Kalutharage*2 and P. Ruchira T. Cumaranatunga ${ }^{1}$ \\ 1 Department of Fisheries and Aquaculture, Faculty of Fisheries and Marine Sciences \& \\ Technology, University of Ruhuna, Matara, Sri Lanka. \\ 2 Department of Chemistry, Faculty of Science, University of Ruhuna, Matara, Sri Lanka.
}

*Correspondence (knishantha@chem.ruh.ac.lk)

https://orcid.org/0000-0003-1783-4530

Received: 09.10.2019 Revised: 20.02.2020 Accepted: 26.02.2020 Published online: 21.03.2020

\begin{abstract}
Sailfin catfish (Pterygoplichthys disjunctivus) has become an invasive species within inland water bodies in Sri Lanka but there are no controlling methods presently. Present study investigates the suitability potential of acid soluble collagen/ gelatin from $P$. disjuctivus, to establish commercial demands for this invasive fish. Samples were collected from Udawalawa Reservoir, Sri Lanka and categorized into two lengths groups according to the length; L1 $(30.6 \pm 2 \mathrm{~cm})$ and L2 $(25.1 \pm 3 \mathrm{~cm})$. Acid soluble collagen was extracted from skin, flesh, bone and fin of $P$. disjuctivus using established acid soluble methods. The average yield of collagen (w/w\%) on wet weight basis from skin, flesh, bone and fin for L1 were 26.20 $\pm 3.32 \%, 10.66 \pm 2.01 \%, 3.40 \pm 0.73 \%, 3.19 \pm 1.79 \%$ and for L2 were $22.96 \pm 2.16 \%, 9.19 \pm 0.72 \%, 3.01 \pm 0.63 \%, 2.84 \pm$ $1.06 \%$, respectively. There were significant differences in average yield of collagen among different tissues of fish within the same length group but there were not among the two length groups $(\mathrm{p} \geq 0.05)$. The moisture content in the collagen extracted from, skin, flesh, bone and fin of L1 were $78.30 \pm 0.1 \%, 84.0 \pm 0.1 \%, 75.18 \pm 1.02 \%$, and $75.45 \pm 0.95 \%$ and for L2 were $80.07 \pm 0.15 \%, 83.86 \pm 1.05 \%, 78.19 \pm 0.95 \%, 77.12 \pm 1.06 \%$ respectively; Similarly, protein contents were $48.14 \pm 1.05 \%$, $54.43 \pm 2.99 \%, 48.14 \pm 0.95 \%$, and $48.56 \pm 0.90 \%$ for $\mathrm{L} 2 \quad 49.29 \pm 1.03,49.13 \pm 0.95 \%, 47.26 \pm 0.95 \%$ and $47.73 \pm 0.95 \%$; lipid content of skin, flesh, bone and fin of L1 were $0.9 \pm 0.1 \%, 0.97 \pm 0.06 \%, 1.08 \pm 0.15 \%$, and $0.89 \pm 0.09 \%$ and for L2 were $0.96 \pm 0.03 \%$, and $0.99 \pm 0.03 \%$, and $1.20 \pm 0.11 \%$, and $1.03 \pm 0.06 \%$ respectively; and ash content of skin, flesh, bone and fin of $\mathrm{L} 1$ were $25.76 \pm 0.95 \%, 22.16 \pm 1.11 \%, 32.16 \pm 0.91 \%$, and $29.18 \pm 0.95 \%$ and for L2 were $34.10 \pm 0.95,22.29 \pm 0.95 \%$, $28.166 \pm 0.9$ and $41.17 \pm 1.00 \%$ respectively. In collagen extracted, \% protein, \%lipid and \%ash were significantly different among flesh, skin, bone and fin within the same length group $(\mathrm{p} \leq 0.05)$ but not among length groups $(\mathrm{p} \geq 0.05)$. UV spectrum and FTIR spectrum of extracted four types of collagen indicated high percentage of collagen. Flesh and skin of $P$. disjuctivus can be recommended as a good source of collagen for potential industrial applications.
\end{abstract}

Keywords: $P$. disjuctivus, control/eradicate, invasive fish, collagen

\section{INTRODUCTION}

Collagen is a well-known most abundant structural protein of vertebrate's which served as the basic building blocks for connective tissues, plays an important role in increasing mechanical strength, maintaining the integrity and rheological possessions of the muscles (Birk and Bruckner 2005). It presents in the extracellular matrix of all connective tissues, including animal bone, cartilage, skin, tendon, teeth and blood vessels (Gelse et al. 2003; Gomez-Guillen 2011). Collagen has extensive range of applications in industries such as in food and beverages, cosmetic, leather, film, biomedical material and pharmaceutical industries (Slade and Levine 1987). In General, commercial collagens are extracted from cattle, pig skin and bone or chicken wastes. There is some limitation of the usage of cattle and pig collagen due to epidemic diseases, religious impediments (Kittiphattanabawon et al. 2005; Gómez-Guillen et al. 2011). There is less significance with collagen extraction from poultry slaughter waste, due to the risk of the transmission of Avian Influenza (Saito et al. 2009). Therefore, there is a great necessity to progress alternatives of collagen resources.

Collagen protein molecule is composed of three a-chains, enfolded around each other into a right-handed super-helix (Wong 1989). Collagen has a specific amino acid composition rich in amino acids hydroxyproline, glycine and proline (Etherington and Sims 1981). Hydroxyproline and hydroxylysine amino acids are unique to 


\section{H.M.G.K. Herath et al.}

collagen, which are important in triple helix stability and glycosylation (Shoulders and Raines 2009).

Fish collagen recognized as an alternative collagen source because it considers as a safer source of collagen compared to that of other animal groups (Zhou et al. 2015). Recently, there has been much concentration in utilization of extracted fish collagen and its derivatives for various types of biomedical products and industrial processes (Karim and Bhat 2009). Collagen extracted from fish has gained more attention, as it provides a cheap source of collagen with easy availability and higher yields (Jongjareonrak et al. 2005). Sujithra et al. (2013) reported that tilapia (Oreochromis niloticus) contained almost similar features (composition of amino acid and thermal stability of $32^{\circ} \mathrm{C}$ ) for mammalian collagen extracted from the porcine skin (with thermal stability of $37.8^{\circ} \mathrm{C}$ ). Fish collagen has lower denaturation temperature and viscosity than mammalian collagen (Kimura et al. 1987). The amino acid composition of fish collagen slightly different from mammalian collagen. Generally, mammalian collagen contains a high amount of hydroxyproline and hydroxylysine and the total amino acid (Karim and Bhat 2009). The fish collagen has less amino acid content as well as the larger amount of methionine than mammalian collagen (Piez and Gross 1961).

There are number of methods reported for collagen extraction. Acid hydrolysis is a common method used to extract collagen. The collagen from raw materials can be extracted using an acidic solution, most commonly $0.5 \mathrm{M}$ acetic acid is used and the resultant collagen is called acid soluble collagen (Nagai and Suzuki 2000).

Sailfin catfish (Pterygoplichthys) is commonly known as a suckermouth catfish native to Central and South America, that has inhabiting the entire Amazon basin since the 1950s (Fuller et al. 1999). Popular species in aquarium trade due to ornamental characters, hardiness and excellent grazing feeding habit, the tendency for cleaning algae from all submerged surfaces including vascular plants (Wu et al. 2011). Species of Pterygoplichthys have been introduced all around the world from South America by the aquarium trade (WakidaKusunoki et al. 1855). Later they have been accidentally or intentionally escaped from the aquaria due to carelessness of aquarium owners, and it has caused an introduction of sailfin catfish into natural water bodies. Consequently, single population colonized successfully in the natural water bodies.

$P$. disjuctivus is one of the most common, fast dispersing invasive and ornamental species in Sri Lanka (Sumanasinghe et al. 2014). Over the past years, $P$. disjuctivus have successfully invaded most inland water bodies throughout Sri Lanka mainly around Udawalawa, Anuradhapura, Colombo, Gampaha, Kandy, Kalutara, and Kurunegala districts. (Wijethunga and Epa 2008; Epa 2014).

The distinctive feeding habits and reproductive behaviours of sailfin cat fish are united with larger size and high population densities which creates significant threats to native fish communities and aquatic habitats (Wijethunga and Epa 2008). Their characteristic omnivorous feeding behaviour remove much of the feeding material in different trophic level in the aquatic habitat. Biota relying on planktonic food, algae, organic matter, and small invertebrates are affected. Feeding on mud and silt cause resuspension of sediments and change substrate, alteration of the food web and habitat (Flecker 1992). Sailfin cat fish bear adaptations that are capable of surviving in harsh environments. Native fish are less resistant to the harsh environmental conditions. Then sailfin cat fish become a successful competitor with native fish due to long lifespan, high population density, high productivity and diversity in trophic levels (Liang et al. 2005). They compete with native fish by overgrazing of algae. Wijethunga and Epa (2008) stated that endemic stone sucker fish, Garra ceylonensis had similar feeding behaviour of $P$. disjuctivus Presence of similar feeding behaviour threatens the existence and extirpation of endemic stone sucker fish in Sri Lanka. Suckermouth catfish are benthic feeders; they ingest eggs of the native fish which cause decline of native fish populations. $P$. disjunctivus attaches to the skin of the 'Endangered (EN)' native Florida manatee and feeds on their epibiota (Nico et al. 2009).

$P$. disjuctivus have being negatively affected the existing fish communities and fisheries in local reservoirs including Udawalawe reservoir. Harvest of food fish has been declined due to the rapid proliferation of sailfin catfish. In Nawayalathenna fish landing site at Polgolla reservoir fish harvest ratio between sailfin catfish and other food fish species was 3: 1 in 2012. Entanglement of different sizes of sailfin catfish into fishing nets caused significant damage to fishing gears (Epa et al. 2014). 
H.M.G.K. Herath et al.

When the sailfin catfish co-exist with other food fish, they start to attach to the skin of food fish via their sucking disk, thereby causing lesions in the skin of food fish. This eventually reduces the flesh quality of the food fish and decrease their market value. This situation widely affects the food fish industry in the country.

Although controlling methods have not been taken to control the sailfin catfish density in the inland waters, it is recommended to carry out projects to use economically these fish. The main objective of the present study is to evaluate the suitability of $P$. disjuctivus for isolate collagen as a valuable biomaterial which could be a suitable control method for sailfin cat fish (Pterygoplichthys sp.) infestation in aquatic system in Sri Lanka. Provide demand for invasive fish species sailfin cat fish by producing a value-added product, collagen which has wide range of applications.

\section{MATERIALS AND METHODS}

Twenty fish samples of tank cleaner fish were collected from the Udawalawe reservoir, Sri Lanka. Collected fish samples were stored in polystyrene ice box with crushed ice until transported to the Fisheries and Aquaculture Laboratory, University of Ruhuna. Fish samples were separated into two length classes L1 (average weights and lengths was $245.06 \pm$ $13.47 \mathrm{~g}$ and $30.65 \pm 1.61 \mathrm{~cm}$ ) and L2 (average weights and lengths was $158.67 \pm 34.75 \mathrm{~g}$ and, $25.07 \pm 2.59 \mathrm{~cm}$, Table 1). All the samples were stored in freezer at $-20^{\circ} \mathrm{C}$ until extraction of collagen.

Acid Soluble Collagen (ASC) was extracted following the method reported by Nagai and Suzuki (2000) with slight modifications. All the procedures for pretreatment, washing, and extraction were carried out at $4^{\circ} \mathrm{C}$. The skins, bones, fins, and flesh from each length classes were separated, labeled and cut into $(0.5 \times 0.5$ $\left.\mathrm{cm}^{2}\right)$ small pieces. The skin and flesh from each length classes were cut into small pieces of 0.5 $\mathrm{cm}$ length. Three subsamples of $50 \mathrm{~g}$ from each sample in each length classe was weighed and soaked in $0.1 \mathrm{M} \mathrm{NaOH}$ at a sample to solution ratio of 1:10 (w/v) to remove non-collagenous proteins. The mixture was stirred 36 hours. In every 12 -hour, solution was changed. Then the samples were washed using cold distilled water until $\mathrm{pH} \approx 7$ was achieved. The deproteinized skins were soaked in 10\% butyl alcohol $(1: 10$ $\mathrm{w} / \mathrm{v})$ in 24 hours to remove fat from the skin.
Then the samples were washed thoroughly with cold distilled water. These skin samples were suspended in $0.5 \mathrm{M}$ acetic acid $(1: 10 \mathrm{w} / \mathrm{v})$ for 72 hours with continuous stirring. It was filtered using a piece of gauze and the filtrate was centrifuged at $6000 \mathrm{rpm}$ for $20 \mathrm{~min}$ using a centrifuge machine. The salts were precipitated according to Nagai and Suzuki (2000) method. The resulting white precipitate was collected by centrifugation at $6000 \mathrm{rpm}$ for $30 \mathrm{~min}$. The weight of wet precipitates was measured using the analytical balance. Wet precipitate was lyophilized using a freeze-drier (YAYMATO SCIENTIFIC CO. LTD, Tokyo, Japan). The freeze-dried samples were weighted using the analytical balance.

The fish head was hammered and backbone was cut into small pieces of $0.5 \mathrm{~cm}$ length. Three subsamples of $50 \mathrm{~g}$ from bone samples in each length classes were weighed pretreated as above procedure. ASC were extracted using procedure described by Nagai and Suzuki (2000). The same procedure was repeated to isolate ASC from the fish fins using $30 \mathrm{~g}$ from fin samples in each length classes.

Final weight of collagen samples was recorded and percentage of yield calculated of each sample using the equation based on wet weight basis.

$$
\text { Yield }(\%)=\frac{\text { Weight of collagem sample }(g)}{\text { Weight of imitial sample }(g)} \times 100
$$

Percentage moisture content and percentage ash content of 24 samples (3 subsamples from 8 collagen samples) were determined by gravimetric method and the total N-content were determined by Kjeldhal method using $0.200 \mathrm{~g}$ of collagen samples (wet weight basis) (AOAC 1990). Using these data percentage crude protein in collagen samples were calculated according to following equation:

\section{Crude protein $(\%)=$ Total $N \% \times C F$,} where, $\mathrm{CF}=$ Conversion factor for nitrogen to protein (6.25).

Percentage of lipid content of the collagen samples obtained from skin, flesh, fin, and bone with each length classes were determined using method described by Folch (1957) using 0.200g of sample weight.

UV absorption spectrum of different collagen samples were obtained by a using a UV-visible Spectrophotometer (Thermo Scientific, EVOLUTION 260 BIO). Five mg of extracted 


\section{H.M.G.K. Herath et al.}

collagen from skin, flesh bone, and fins from $P$. disjuctivus were dissolved in $10 \mathrm{~mL}$ of $0.5 \mathrm{M}$ acetic acid solutions and centrifuged at $6000 \mathrm{rpm}$ for 5 minutes. The solution was placed into a quartz cell with path length of $1 \mathrm{~mm}$ and spectrum was measured wavelength range 210 $400 \mathrm{~nm}$ against the blank at a scan speed of $2 \mathrm{~nm}$ per second with an interval of $1 \mathrm{~nm}$. The blank was prepared following same procedure except sample.

Hydroxyproline content was determined using UV-visible spectrophotometric method (Stegemann and Stalder 1967) and collagen\% was calculated accordingly. The lyophilized collagen samples from skin, flesh, bone and fin were characterized by Fourier Transformed InfraRed (FT-IR) spectroscopy instrument (Varian 660-IR) at the Department of Chemistry of the University of Colombo, Sri Lanka using $\mathrm{KBr}$ pellet method. The peaks were identified and assigned according to the literature values.

The water retention capacity was evaluated by the percentage of residual water of the wet sample method by Chun-Yung Huang (2016).

Sensory evaluation conducted by using a 12member panel. One sample of each freeze-dried collagen samples from skin, flesh and fin were kept in vials and were lightly closed. Then induvial are allowed to detect the odor and color one by one. Panelists were open the vials and smell the content and observe the color. Identified odor and color they perceived, indicate the odor and color intensity. The nine-point hedonic scale $(1=$ no odor, $5=$ middle odor, $9=$ very strong and offensive odor) and threepoint hedonic scale $(1=$ pure white, $2=$ white, 3 $=$ yellowish white).

Reported data of the extracted yields for different collagens were based on the average from triplicates. Experiments were performed in triplicated and results were represented as means \pm standard deviation. A probability value of $\leq$ 0.05 was considered as a significant. Statistical analysis was assessed by the One -way Analysis of Variance (ANOVA) and t- test. Differences between variables evaluated by Duncan's multiple-range test. Analysis was performed by using SPPS 16.0 for windows software package.

\section{RESULTS}

Table 1 represents the total length and the mean weight and relative proportions of each body parts of length classes L1 and L2 of P. disjuctivus There was a significant difference in $(n=10, \mathrm{p} \leq$ 0.05 ) mean total length and mean body weight of two length classes. Relative proportion of $\%$ flesh, $\%$ bones, $\%$ skin and $\%$ fin was $28.16 \%$, $23.19 \%, 20.87 \%$ and $6.13 \%$ in L1 length class and $27.60 \%, 22.8 \%, 18.91 \%$ and $5.43 \%$ in L2 length class respectively. Highest proportion was obtained from flesh followed by the bone and skin. According to that flesh account for highest part of the body bones and skin followed by then.

Table 1 Length, mean weight, and relative proportions (\%) of different tissues of $P$. disjuctivus of two selected length groups

\begin{tabular}{lllllll}
\hline $\begin{array}{l}\text { Length } \\
\text { Class }\end{array}$ & $\begin{array}{l}\text { Mean total } \\
\text { length }(\mathrm{cm})\end{array}$ & $\begin{array}{l}\text { Mean weight } \\
(\mathrm{g})\end{array}$ & Skin (\%) & Flesh (\%) & Bone (\%) & Fin (\%) \\
\hline L1 & $30.7 \pm 1.6$ & $245.06 \pm 13.47$ & $20.87 \pm 1.21^{\mathrm{b}}$ & $28.17 \pm 2.62^{\mathrm{d}}$ & $23.19 \pm 2.09^{\mathrm{c}}$ & $6.13 \pm 0.81^{\mathrm{a}}$ \\
L2 & $25.1 \pm 2.6$ & $158.67 \pm 34.75$ & $18.91 \pm 2.64^{\mathrm{b}}$ & $27.60 \pm 2.42^{\mathrm{d}}$ & $22.80 \pm 1.98^{\mathrm{c}}$ & $5.43 \pm 0.37^{\mathrm{a}}$ \\
\hline
\end{tabular}

(Number of samples $n=10$ )

Different superscripts in the same column indicate significant differences $(\mathrm{p} \leq 0.05)$.

Table 2 shows the yield of ASC extracted wet weight basis from four different tissues of sailfin cat fish. Extracted yield of ASC from skin in the L1 and L2 length classes of $P$. disjuctivus were $(26.20 \pm 3.32 \%)$ and $(22.95 \pm 2.16 \%)$, respectively and there was no significant difference in yield of skin collagen in between length classes ( $p \geq 0.05$ ). Similarly, there were no significant difference in yield of collagen in between each body parts in two length classes ( $p$ $\geq 0.05$ ). Higher yield was obtained from the skin and flesh than for the bone and fins in both L1 and L2 length classes. 
Table 2 Yield of ASC extracted from skin, flesh, bone and fins of $P$. disjuctivus.

\begin{tabular}{lll}
\hline Length class & Tissue & \% yield of ASC \\
\hline L1 & Skin & $26.20 \pm 3.32^{\mathrm{c}}$ \\
& Flesh & $10.66 \pm 2.01^{\mathrm{b}}$ \\
& Bone & $3.40 \pm 0.73^{\mathrm{a}}$ \\
L2 & Fin & $3.19 \pm 1.79^{\mathrm{a}}$ \\
& Skin & $22.96 \pm 2.16^{\mathrm{c}}$ \\
& Flesh & $9.19 \pm 0.72^{\mathrm{b}}$ \\
& Bone & $3.01 \pm 0.63^{\mathrm{a}}$ \\
& Fin & $2.84 \pm 1.06^{\mathrm{a}}$ \\
\hline
\end{tabular}

(Samples size $\mathrm{n}=3$ ); Different superscripts in the same column indicate significant differences $(\mathrm{p} \leq$ $0.05)$.

Proximate analysis of collagen extracted from skin, flesh, bone and fins of $P$. disjuctivus based on the dry weight and wet weight represents in table 3 including parameters such as mean \% moisture, \%ash, $\%$ crude protein and \%crude fat values in each collagen samples which extracted from different tissues in two length classes L1 and L2. The percentage moisture content of collagen samples from skin, flesh, bone and fin of $P$. disjuctivus were significantly different within the length class $(\mathrm{p} \leq 0.05)$. The mean moisture content in collagen from skin, flesh fin and bone were not significantly different between the two length classes, L1 and L2. The maximum moisture content was observed in the collagen from flesh as $84.0 \pm 0.10$ and $83.863 \pm 1.05$ in L1 and L2 length classes respectively. The highest ash (\%) was represented in the collagen from bone and fin in both length classes and it was $32.16 \pm 0.91,28.16 \pm 0.90$ and $29.18 \pm 0.95,41.7 \pm 1.00$ in L1 and L2 length classes respectively. A significant difference $(p \leq 0.05)$ was observed in the Ash $(\%)$ of collagen from skin, flesh, fin and bone within the same length class. No significant difference in was observed in ash $(\%)$ in the collagen from skin, flesh fin and bone between two length classes ( $\mathrm{p} \geq 0.05$ ).

Table 3 Proximate analysis of collagen extracted from skin, flesh, bone and fins of $P$. disjuctivus based on the dry weight and wet weight

\begin{tabular}{llccll}
\hline $\begin{array}{l}\text { Length } \\
\text { Class }\end{array}$ & Tissue & $\%$ moisture \pm SD & \% Ash \pm SD & $\begin{array}{l}\text { \%Crude protein } \pm \\
\text { SD }\end{array}$ & $\begin{array}{l}\text { \%Crude fat } \\
\pm S D\end{array}$ \\
\hline \multirow{2}{*}{ L1 } & Skin & $78.30 \pm 0.1^{\mathrm{b}}$ & $25.77 \pm 0.95^{\mathrm{b}}$ & $48.15 \pm 1.05^{\mathrm{a}}$ & $0.90 \pm 0.102^{\mathrm{a}}$ \\
& Flesh & $84.0 \pm 0.1^{\mathrm{c}}$ & $22.16 \pm 1.11^{\mathrm{a}}$ & $54.44 \pm 2.99^{\mathrm{b}}$ & $0.97 \pm 0.06^{\mathrm{a}}$ \\
& Bone & $75.18 \pm 1.0^{\mathrm{a}}$ & $32.16 \pm 0.91^{\mathrm{d}}$ & $48.14 \pm 0.95^{\mathrm{a}}$ & $1.08 \pm 0.15^{\mathrm{a}}$ \\
& Fin & $75.475 \pm 0.95^{\mathrm{a}}$ & $29.18 \pm 0.95^{\mathrm{c}}$ & $48.56 \pm 0.9^{\mathrm{a}}$ & $0.89 \pm 0.09^{\mathrm{a}}$ \\
L2 & Skin & $80.07 \pm 0.15^{\mathrm{b}}$ & $34.10 \pm 0.95^{\mathrm{c}}$ & $49.29 \pm 1.03^{\mathrm{c}}$ & $0.96 \pm 0.03^{\mathrm{a}}$ \\
& Flesh & $83.86 \pm 1.05^{\mathrm{c}}$ & $22.29 \pm 0.95^{\mathrm{a}}$ & $49.13 \pm 0.95^{\mathrm{ab}}$ & $0.99 \pm 0.01^{\mathrm{a}}$ \\
& Bone & $78.19 \pm 0.95^{\mathrm{a}}$ & $28.16 \pm 0.90^{\mathrm{b}}$ & $47.26 \pm 0.95^{\mathrm{a}}$ & $1.21 \pm 0.11^{\mathrm{b}}$ \\
& Fin & $77.13 \pm 1.06^{\mathrm{a}}$ & $41.17 \pm 1.00^{\mathrm{d}}$ & $47.73 \pm 0.95^{\mathrm{ab}}$ & $1.03 \pm 0.06^{\mathrm{a}}$ \\
\hline
\end{tabular}

(Number of samples $(n)=3$ )

Different superscripts in the same column indicate significant differences $(\mathrm{p} \leq 0.05)$. 


\section{H.M.G.K. Herath et al.}

Proximate analysis of the collagen from skin, flesh, fin and bone in $P$. disjuctivus revealed a significant different in protein content in L1 group ( $\mathrm{p} \leq 0.05)$. However, no significant difference was observed in protein content in collagen from different tissues within L2 length group. The two-length class L1 and L2 revealed non-significance with respect to protein $(\%)$ in collagen samples. The highest crude protein (\%) was represented in the collagen from flesh in both length classes and it was $54.44 \pm 3,49.13$ \pm 0.9 in L1and L2 length classes respectively. The highest crude fat (\%) was represented in the collagen from bone in both length classes and it was $1.08 \pm 0.15,1.21 \pm 0.11$ in L1 and L2 length classes respectively. The crude fat content from collagen from different tissues were not significantly different in L1 length class $(\mathrm{p} \geq$ $0.05)$.

The crude fat content in extract collagen from different tissues were significantly different

Table 4 Percentage of hydroxyproline, calculated collagen and protein from collagen extracted from different tissues of $P$. disjuctivus (Dry weight basis) at two length class (L1 and L2)

\begin{tabular}{lcccc}
\hline Length class & Tissue & Hydroxyproline \% & Collagen \% & Protein \% \\
\hline \multirow{2}{*}{ L1 } & skin & 9.37 & 69.87 & 80.19 \\
& Flesh & 2.14 & 15.98 & 76.37 \\
& Bone & 7.57 & 56.46 & 62.02 \\
L2 & Fin & 8.99 & 67.13 & 70.11 \\
& skin & 7.96 & 59.37 & 74.31 \\
& Flesh & 1.52 & 11.37 & 89.27 \\
& Bone & 7.28 & 54.27 & 68.76 \\
& Fin & 7.57 & 56.46 & 66.25 \\
\hline
\end{tabular}

The maximum absorbance wavelengths for particular collagen samples were shown in Table 5. Figure 1 illustrates the UV absorption spectra of extraction collagen contains maximum absorption peak at 236$242 \mathrm{~nm}$ with little absorption peak at 271-283 $\mathrm{nm}$. Absorption spectra of collagen from within L2 length class. The comparison of fat content in collagen from flesh in two length classes were represented there were significant difference. However, collagen from fin skin and bone were not significantly different in between length classes.

Table 4 shows percent of hydroxyproline and collagen from extract collagen (dry weight basis) in different tissues in $P$. disjuctivus. The highest Hydroxyproline (\%) was obtained from skin and fins in both length classes. The protein (\%) in the extracted collagen from flesh was very high $(76.37 \%)$ with very low hydroxyproline $(2.14 \%)$ and collagen content. Protein content in the extracted collagen from fins were little bit lower than protein content in skin collagen. But relatively collagen from fin contain had higher hydroxyproline (\%) than collagen from skin. flesh, skin and bone depict maximum absorbance peak in nearly same region (242$243 \mathrm{~nm})$. Absorbance spectra of collagen from fin slightly deviate from other three spectrums. Absorbance spectra of collagen from bone and fin contain little absorbance peak at $280 \mathrm{~nm}$.

Table 5 Absorbance of collagen extracted from different tissues of $P$. disjuctivus

\begin{tabular}{lll}
\cline { 2 - 3 } Tissue & $\chi \max (\mathrm{nm})$ & Absorbance \\
\cline { 2 - 3 } Skin & 242.06 & 1.912 \\
& 279.12 & 0.897 \\
Flesh & 243.01 & 1.481 \\
& 276.05 & 0.753 \\
Bone & 242.99 & 1.242 \\
& 283.91 & 0.412 \\
\multirow{2}{*}{ Fin } & 236.02 & 1.336 \\
& 271.24 & 0.703 \\
\hline
\end{tabular}


H.M.G.K. Herath et al.

The FTIR spectra of collagen from different tissues of $P$. disjuctivus exhibited characteristics peaks assigned to the bonds: amide I, II, III and Amide A, B (Figure 2). The major peak locations of FTIR spectra of collagen from different tissues of $P$. disjuctivus were provided in Table 6. The amide A band positioned range from 3234$3456 \mathrm{~cm}-1$ in collagen from skin, flesh bone and fin. The peak corresponding to amide B was clearer in collagen from fin, whereas amide $\mathrm{B}$ was significantly reduced in collagen from skin and flesh. The amide I band position of extracted collagen from different tissues were range from 1636- 1650 $\mathrm{cm}-1$ fitting well the range is $1600-1700 \mathrm{~cm}$ -
1 for Amide I band. The Amide II peaks (1552-1557 cm-1) located in slightly same position in four collagen samples. Amide III band were observed at wavenumber 1276$1278 \mathrm{~cm}-1$ in spectra of four collagen samples. The ruggedness of the peaks between Amide I, II, and III was more obvious in the collagen from fin compared to another collagen samples (Figure 1). The IR absorption ratio in between amide III and $1450 \mathrm{~cm}-1$ were collagen from skin, flesh, bone and fin were 1.0, 1.07, 1.1, 1.05 respectively. That indicate the collagen from different tissues with triple helix structure.

Table 6 FTIR peak locations of collagen extracted from different tissues of $P$. disjuctivus

\begin{tabular}{lcccc}
\hline Region & \multicolumn{4}{c}{ Peak wave number $\left(\mathrm{cm}^{-1}\right)$} \\
\cline { 2 - 5 } & Skin & Flesh & Bone & Fin \\
\hline Amide I & 1636.9 & 1637.5 & 1638.2 & 1650.4 \\
Amide II & 1557.1 & 1557.0 & 1558.3 & 1552.9 \\
Amide III & 1025.4 & 1276.7 & 1274.3 & 1278.8 \\
Amide A & 3456.9 & 3434.4 & 3426.7 & 3241.7 \\
Amide B & & & 2899.1 & 2951.6 \\
\hline
\end{tabular}

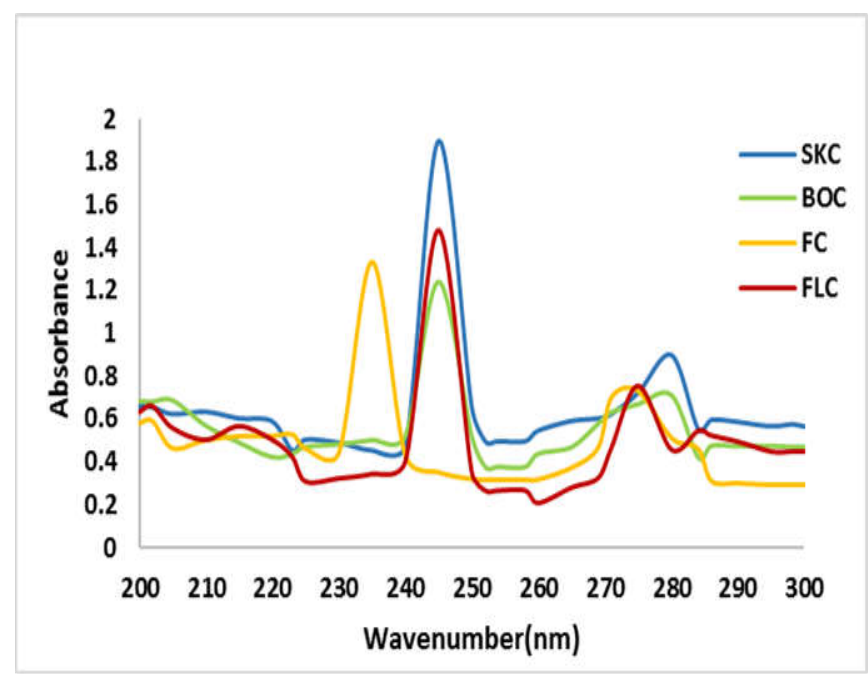

Fig 1 UV-vis spectrum of collagen from different tissues of $P$. disjuctivus $(\mathrm{SKC}=$ collagen from skin, $\mathrm{FLC}=$ collagen from flesh, $\mathrm{BOC}=$ collagen from bone, $\mathrm{FC}=$ collagen from fin) 


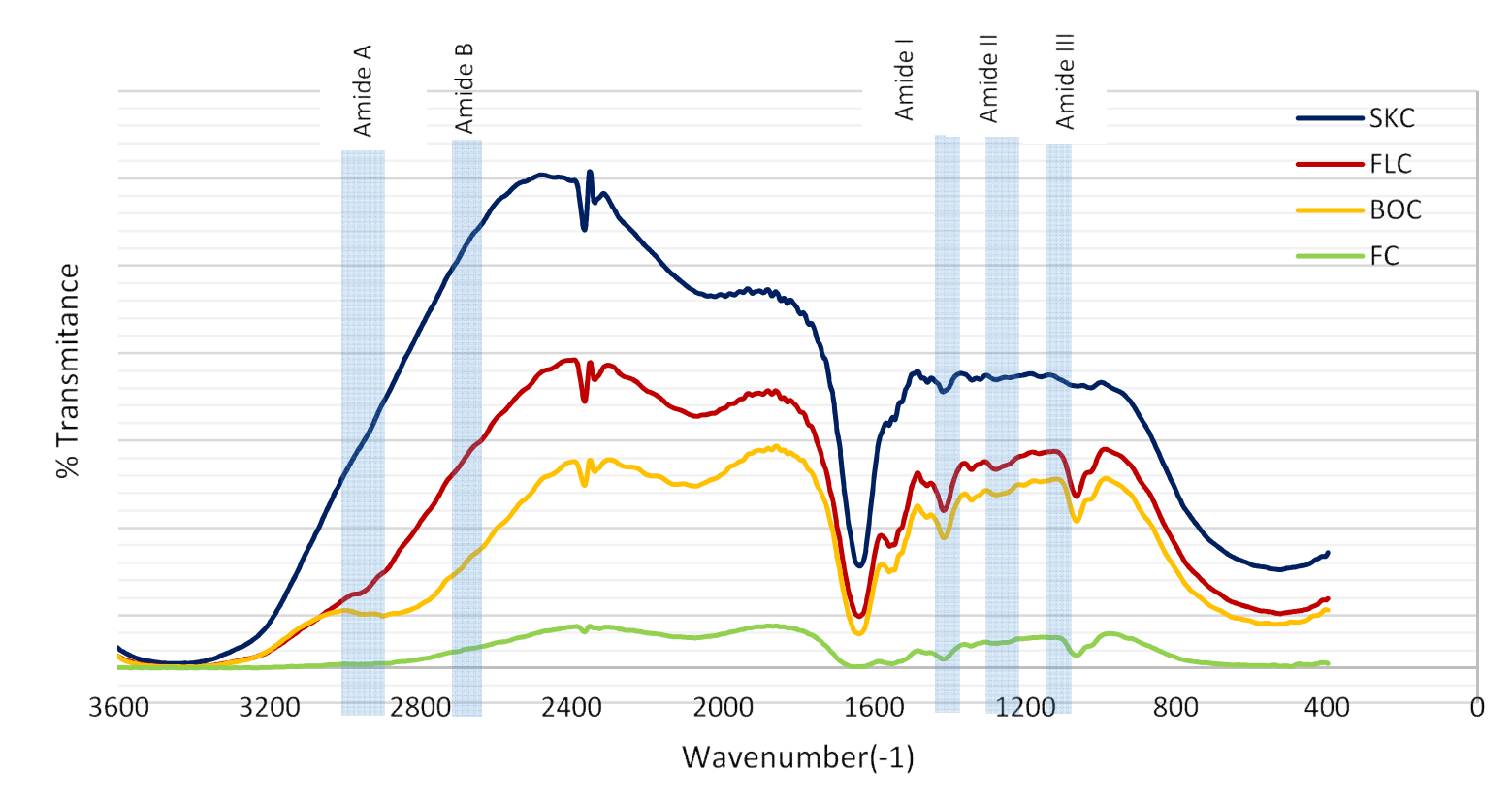

Fig 2 FTIR spectrum of collagen extracted from different tissues of $P$. disjuctivus (SKC= collagen from skin, $\mathrm{FLC}=$ collagen from flesh, $\mathrm{BOC}=$ collagen from bone, $\mathrm{FC}=$ collagen from fin)

The water retention capacity of extracted collagen from different tissues were represented in table 7. There were no significant difference

among the water retention capacity of collagen from different tissues $(\mathrm{p} \geq 0.05)$.

Table 7 Water Retention capacity (WRC) \% of collagen extracted from skin, flesh bone and fin

\begin{tabular}{ll}
\hline Sample & WRC $(\%) \pm$ SD \\
\hline Collagen from skin & $15.39 \pm 0.64$ \\
collagen from flesh & $14.70 \pm 1.05$ \\
collagen from bone & $15.14 \pm 0.38$ \\
collagen from fin & $15.27 \pm .33$
\end{tabular}

(Number of samples $(\mathrm{n})=3$ ); Different superscripts in the same column indicate significant differences $(\mathrm{p} \leq 0.05)$.

Table 8 evaluates odor and color of the extracted collagen from skin, flesh, bone and fin of the $P$. disjuctivus. There was no significant difference between odors of the collagen from different tissues $(p \geq 0.05)$. Collagen from bone

and fin exhibited the least odor comparatively collagen from skin and flesh. There was significant difference in between color of the extracted collagen $(\mathrm{p} \leq 0.05)$. 
H.M.G.K. Herath et al.

Table 8 Sensory evaluation of offensive odor for collagen samples from skin, flesh, bone and fin

\begin{tabular}{lll}
\hline Sample & Odor & Color \\
\hline Collagen from skin & $5.08 \pm 0.9$ & $1.58 \pm 0.7^{\mathrm{a}}$ \\
collagen from flesh & $5.41 \pm 1.1$ & $2.33 \pm 0.8^{\mathrm{b}}$ \\
collagen from bone & $4.66 \pm 0.8$ & $1.66 \pm 0.5^{\mathrm{a}}$ \\
collagen from fin & $4.66 \pm 0.8$ & $1.41 \pm 0.5^{\mathrm{a}}$
\end{tabular}

(Number of samples $\mathrm{n}=12$ ); Different superscripts in the same column indicate statistical differences ( $\mathrm{p} \leq 0.05)$; Hedonic scale ( $1=$ no odor: $5=$ middle odor: $9=$ Very strong and offensive odor $)(1=$ Pure white: $2=$ white: $3=$ yellowish white $=3$ ).

\section{DISCUSSION}

Sailfin catfish is an invasive species distributed in inland water system including, Kala wewa, Hurulu Wewa, Victoria and Udawalawe Reservoirs and other reservoirs in western province in Sri Lanka (Epa 2014). They bear a wide range of adaptation, hence causing population growth and creating larger threats to inland water system. Sailfin catfish does not hold any market value. When fish were get caught into the nets they thrown banks of the reservoir or kill in that place. Unpleasant appearance, rough skin and more indigestible part when compare to the other fish cause to reduce the consumer demand. Consumption is an only way to control the present population of sailfin catfish. In order to create the market demand for fish post-harvest technologies are applying (Ariyarathna et al. 2013). Utilization of total fish important rather than usage of part of the fish. It will have increased the demand of the fish.

According to results sailfin catfish account for $20 \%$ skin, $23 \%$ bone, $28 \%$ flesh and $6 \%$ fin in total body weight. These body parts can be used as an initial raw material to extract collagen. Usable portion for extracting of collagen accounts approximately $75 \%$ of total body weight. As this is a considerable amount, the commercial value of the fish could be increased.

Yield of collagen extracted from Sailfin catfish skin, flesh, bone and fin varied from $2 \%$ to $26 \%$ in wet weight basis. The percentages of collagen yield obtained from skin of Pterygoplichthys sp. was $26.20 \%$ and $22.95 \%$ in L1 and L2 classes respectively. The collagen yield of ASC from different fish skins has been reported on wet weight basis as $9.0 \%$ for brown stripe red snapper, (Jongjareonrak et al. 2005), 17 $\%$ for horse mackerel, $21.9 \%$ for croaker (Kumar and Nazeer 2013), $18.11 \%$ for Malaysian cat fish (kiew and mashitah 2013), $13.68 \%$ for Spanish mackerel (Rui Li et al. 2013) and $17.5 \%$ for big head carp (Liu et al. 2012). When comparing with these values, the yield of collagen that can be extracted from skin of Pterygoplichthys sp. was higher. However, the amount of collagen that can be extracted from the current study was slightly lower than that of deep-sea redfish about $41.7 \%$ (Wang et al. 2008) and oscillate puffer fish (44.7\%) (Nagai et al. 2002). The presence of high content of cross links with covalent bond in the telopeptide region of the collagen molecule decreases the solubility of collagen (Foegeding et al. 1996). Therefore, increase in the crosslinks might be the reason for the reduction in the resultant collagen yield.

Yield of collagen extracted from Sailfin catfish from bone and fin varied with the $3 \%$ to $2 \%$ in wet weight basis. Bone and fin collagen of other species reported that $1.3 \%$ and $2.0 \%$ respectively (Liu et al. 2012), bone collagen (42 $\%)$ in skipjack tuna, fin collagen $(5.2 \%)$ in Japanese sea-bass (Nagai and Suzuki 2000). Yield of collagen extracted from sailfin catfish flesh was $10.6 \%$ on wet weight basis. Other projects revealed that the yield of collagen from flesh of Bester sturgeon was $0.4 \%$ on wet weight basis, (Zhang et al. 2014). The variation in the yield of collagen obtained by could be due to variation in the extraction conditions such temperature, homogenization and time duration and biological conditions of fish species.

The proximate composition of collagen from flesh contained high moisture, it may be initial 


\section{H.M.G.K. Herath et al.}

flesh samples which subjected to extraction contain high moisture content than skin, bone and fin. Although collagen from flesh contains high protein (\%), hydroxyproline and calculated collagen (\%) were lowered than other collagen extracted from different tissues. Collagen from flesh contain low ash content. It may be low mineralization of flesh than other tissues such bone and skin. The proximate composition of collagen from flesh was not different with length classes. So, collagen from flesh in two length classes contain same composition. Higher ash content noticed in the collagen from skin, fin and bone, it was due to mineralization of the tissue. The ash content in skin comparatively lower than fin and bone but, ash (\%) of collagen from skin relatively high due to scavenger fish has thicker skin and present of scales modifications in the surface of the skin. Presence of relatively high collagen content in the skin, made them good sources for collagen extraction.

There was no significant variation in the proximate composition in collagen extracted from different tissues in between the L1 and L2 classes. From that collagen from skin from L1 and L2 classes were contain same proximate composition. Same followed by other collagen obtained from bone, flesh and fins. Proximate composition of collagen extract from flesh, fin and bone were not significantly different in between the L1 and L2 classes respectively.

UV-Vis spectrum is a simple way to characterize the extracted collagen. The four spectra of the collagen from skin, flesh, bone and fin were exhibited maximum absorbance peak at $\approx 235-245 \mathrm{~nm}$ with low absorbance peak at 280 $\mathrm{nm}$. The absorbance at $235-245 \mathrm{~nm}$ are due to Phenylalanine while other peak $\approx 280 \mathrm{~nm}$ are attributed to other aromatic amino acids such as tyrosine, tryptophan in extracted collagen. From that collagen extracted from different tissues of $P$. disjuctivus contains tyrosine, tryptophan and phenylalanine. Tryptophan and Phenylalanine are absorbed UV light at $280 \mathrm{~nm}$ and $258 \mathrm{~nm}$ (Schmid 2001). Presence of typical maximum absorption peaks in the collagen obtained from different tissues of $P$. disjuctivus indicate the efficient removal of non-removal collagen in the collagen extraction process. Hence it might be suggested that, Type I collagen from different tissues of sailfin cat fish was obtained without contamination of other proteins.

Hydroxyproline amino acid exclusively specific for the collagen and it covers $14 \%$ of collagen weights. Presence of hydroxyproline indicate the presence of collagen in extracted protein. The percentage of hydroxyproline provide clue thermal stability of particular collagen degree of stabilization in triple helix structure of peptide (Rosenblo et al. 1973). Hydroxyproline has been used to quantify the amount of collagen in a particular tissue. Calculated collagen \% useful for the estimate the purity of the resultant collagen. Presence of higher hydroxyproline content in collagen from skin and fin bone indicate the higher denature temperature and stabilization of the triple helix structure. Collagen extracted from skin and fins of $P$. disjuctivus were contain higher hydroxyproline content than collagen from flesh and bone. Although skin collagen contains higher hydroxyproline content than collagen from fin comparatively ratio of the calculated collagen $(\%)$ to protein (\%) was lower than collagen from fin. The ratio of calculated collagen $(\%)$ to protein (\%) were high in fin and followed by skin and bone. Lowest ratio represented by collagen from flesh. Collagen from flesh contain high protein (\%), but calculated collagen (\%) is low. From that though initially considerable amount of yield of collagen from present, availability of collagen content slightly is low in flesh.

The FTIR spectra of collagen from skin, flesh, bone and fin of sailfin catfish exhibited the characteristic peaks of amide I, II, III and amide A. Amide A band observed in normal absorption range $\left(3300 \mathrm{~cm}^{-1}\right)$, and it has commonly linked with the N-H frequency. When the position of the NH group, where located in peptides associated with $\mathrm{H}$ bonds, caused to shift into lower frequency comparatively normal range position of amide A band. Hence, movement of amide A band indicate the existence of hydrogen bonding in each collagen (Muyonga et al. 2004). The amide I, II, III bands are related to the degree of molecular order and its involvement of triple helix structure of collagen. Amide I band with characteristic absorbance range position in from (1700-1600 $\mathrm{cm}^{-1}$ ) related to $\mathrm{C}=\mathrm{O}$ stretching vibrations of the polypeptide back bone. Amide I is a sensitive marker of the protein secondary structure (Muyonga et al. 2004). The amide I bands of collagen extract from fin was positioning in $1650 \mathrm{~cm}^{-1}$ and it was slightly higher than wavenumber corresponding in to collagen obtained from flesh, bone and skin collagen. It might be suggested that fin collagen contain slightly higher molecular order than other three types of collagen. Amide II band normally located from $\left(1480-1575 \mathrm{~cm}^{-1}\right)$. Amide II band 
H.M.G.K. Herath et al.

derives from $\mathrm{NH}$ bending and $\mathrm{CN}$ stretching vibration (Muyonga et al. 2004). The Amide II band of collagen from skin, flesh bone and fin were not containing larger variations. Amide II band observed in collagen extracted from four tissues from $\left(1552-1558 \mathrm{~cm}^{-1}\right)$ range, that indicate vibration of $\mathrm{NH}$ bending coupled with stretching vibration of $\mathrm{CN}$. The Amide III bond characteristic absorbance range observed from $\left(1220-1320 \mathrm{~cm}^{-1}\right)$, that involved with configuration of triple helix structure. Collagen from skin, flesh bone and fin were confirmed from the absorption ratios between amide III and $1450 \mathrm{~cm}^{-1}$ bands which are ranged from 1.0-1.05. The ratio of the IR absorption intensities between amide III and $1450 \mathrm{~cm}^{-1}$ bands were nearly equal to 1.0 , confirm the triple helix structure of the collagen present (Guzzi-pelpis et al. 1996).

Although the characteristic peaks which specific to collagen were present in the amide band region, there some slight differences could be observed among the FTIR spectra of the collagen obtained from skin, flesh, bone and fin. It indicates collagen obtained from different tissues contain some slight differences in secondary structures. FTIR spectra of extracted collagen confirming that the triple helix structures were well maintained and suggested that their secondary structures were relatively similar.

Results of the present study showed that collagen extracted from the $P$. disjuctivus with promising yield from fish skin, compared to fish flesh, bone and fins. Characterization of extracted collagen, four types are characterized with wellmaintained triple helix structure. Present study was successes to investigate suitability of $P$. disjuctivus for isolate collagen, which is valuable biomaterial. If there was an effective market exploitation of sailfin cat fish, it could not consider as a waste. It has become an important fishing resource due to availability in most of the inland water system. Utilization of sailfin catfish as a source for the isolate collagen provide effective method of control present population of $P$. disjuctivus, can produce value-added products, control its population and even create new employment, business opportunities.

The potential applications of collagen include medicine for osteoarthritis, hypertension, use in tissue engineering, implants in human, inhibition of angiogenic diseases, etc. (Rehn et al. 2001). It is also used for drug delivery, skin substitutes, expandable intra-arterial stents and cell attachment substrate (Senaratne et al. 2006).
Gelatine is a partially hydrolysed form of collagen and uses in food and packaging industry for microencapsulation and light sensitive coatings (Senaratne et al. 2006).

\section{ACKNOWLEDGEMENTS}

Authors are thankful to Department of Fisheries and Aquaculture and Department of Chemistry of the University of Ruhuna, Sri Lanka for providing necessary laboratory and library facilities.

\section{REFERENCES}

AOAC 1990. Official Methods of Analysis of the Official Associate of Analytical Chemist, 15 th Ed. Arlington, Virginia, USA.

Ariyarathna, D.S., S.B.N. Ahmad, B.K.K.K. Jinadasa, I. Wickramasinghe and J.H.K.N., Jayawardena 2014. Evaluation of importance of Orinoco Sailfin Catfish (Pterygoplichthys multiradiatus) as a food source. Paper presented at a national conference, Institute of Post-Harvest Technology, National Aquatic Resources Research \& Development Agency, Colombo.

Birk, D.E. and P. Bruckner 2005. Collagen Suprastructures. In: Collagen. Tropics in current chemistry. Berlin: Springer, pp. 185205. https://doi.org/10.1007/b103823

Epa, U.P.K. 2014. Aquaculture and aquarium industries as sources of invasive species in aquatic ecosystems in Sri Lanka. Proceedings of the National Symposium on Invasive Alien Species (IAS 2014), Colombo.

Etherington, D.J. and T.J. Sims 1981. Detection and estimation of collagen. Journal of the Science of Food and Agriculture 32(6):539546. https://doi.org/10.1002/jsfa.2740320603

Flecker, A.S. 1992. Fish Predation and the Evolution of invertebrate drift periodicity: evidence from neotropical streams. Ecology 73: 438-448. http://dx.doi.org/10.2307/1940751.

Foegeding, E.A., T.C., Lanier and H.O. Hultin, 1996. Collagen. In O.R. Fennema (Ed.), Food chemistry (3rd ed.), pp. 902-906. Marcel Dekker, Inc., New York.

Folch, J., M. Lees and G.H.S. Stanley 1957. A simple method for the isolation and purification of total lipids from animal tissues. Journal of Biological Chemistry 226:497-509. 


\section{H.M.G.K. Herath et al.}

Fuller, P.L., L.G. Nico and J.D. Williams 1999. Nonindigenous fishes introduced into inland waters of the United States. American Fisheries Society Special Publication, p.27

Gelse, K., Pöschl, E. and Aigner, T., 2003. Collagens-structure, function, and biosynthesis. Advanced Drug Delivery Reviews, 55(12):1531-1546. DOI: 10.1016/j.addr.2003.08.002

Gómez-Guillen, M.C., Giménez, B., LópezCaballero, M.A. and Montero, M.P., 2011. Functional and bioactive properties of collagen and gelatin from alternative sources: A review. Food Hydrocolloids 25(8):18131827.

https://doi.org/10.1016/j.foodhyd.2011.02.00 7.

Guzzi Plepis, A.M., G. Goissis and D.K., Das-Gupta 1996. Dielectric and pyroelectric characterization of anionic and native collagen. Polymer Engineering and Science 36: 2932-2938. doi:10.1002/pen.10694.

Huang, C-Y., J- M. Kuo, S.-J. Wu, H.-T. Tsai, 2016. Corrigendum to "Isolation and characterization of fish scale gelatin from tilapia (Oreochromis sp.) by a novel extrusion-hydro-extraction process". Food Chemistry 190(1):997-1006. DOI 0.1016/j.foodchem.2015.09.058.

Jongjareonrak, A., S. Benjakul, W. Visessanguan, T. Nagai and M. Tanaka, 2005. Isolation and characterization of acid and pepsin-solubilized collagens from the skin of Brown stripe red snapper (Lutjanus vitta). Food Chemistry 93(3):475-484. https://doi.org/10.1016/j.foodchem.2004.10.0 26.

Karim, A.A. and R. Bhat 2009. Fish gelatin: properties, chalenges, and prospects as an alternative to mammalian gelatins. Food Hydrocolloids 3(23):563-576. https://doi.org/10.1016/j.foodhyd.2008.07.00 2.

Kiew, P.L. and M.D. Mashitah 2013. Isolation and characterization of collagen from the skin of Malaysian catfish (Hybrid Clarias sp.), Journal of the Korean Society for Applied Biological Chemistry 56: 441-450. https://doi.org/10.1007/s13765-013-3114-9.

Kimura, S., Ohno, Y., Miyauchi, Y., and Uchida, N. 1987. Fish skin type I collagen: Wide distribution of an $\alpha 3$ subunit in teleosts. Comparative Biochemistry and Physiology Part B: Biochemistry \& Molecular Biology 88 (1):27-34.
Kittiphattanabawon, P., S. Benjakul, W. Visessanguan, T. Nagai and M. Tanaka 2005. Characterization of acid-soluble collagen from skin and bone of bigeye snapper (Priacanthus tayenus). Food Chemistry 89(3):363-372.

https://doi.org/10.1016/j.foodchem.2004.02.0 42.

Kumar, N.S. and R. Nazeer 2013. Characterization of acid and pepsin soluble collagen from the skin of horse mackerels (Magalapis cordyla) and Croaker (Otolithes rruber). International Journal of Food Properties 16(3): 613-621. https://doi.org/10.1080/10942912.2011.5577 96

Li, Z-R., B. Wang, C-f. Chi et al. 2013. Isolation and characterization of acid soluble collagens and pepsin soluble collagens from the skin and bone of Spanish mackerel (Scomberomorous niphonius). Food Hydrocolloids 31:103-113.

https://doi.org/10.1016/j.foodhyd.2012.10.00 1.

Liang, S.H., H.P. Wu and B.S. Shieh 2005. Size structure, reproductive phenology, and sex ratio of an exotic armored catfish (Liposarcus multiradiatus) in the Kaoping River of southern Taiwan, Zoological Studies 44(2):252-259.

Liu, D., L. Liang, J. M. Regenstein and P. Zhou 2012. Extraction and characterisation of pepsin-solubilised collagen from fins, scales, skins, bones and swim bladders of bighead carp (Hypophthalmichthys nobilis). Food Chemistry 133:1141-1448. https://doi.org/10.1016/j.foodchem.2012.02.0 32.

Muyonga, J., C. Cole, and K. Duodu 2004. Characterization of acid soluble collagen from skins of young and adult Nile perch (Lates niloticus). Food Chemistry 85:81-89. https://doi.org/10.1016/j.foodchem.2003.06.0 06.

Nagai, T. and N. Suzuki 2000. Isolation of collagen from fish waste material-skin, bone and fin. Food Chemistry 68:277-281. https://doi.org/10.1016/S03088146(99)00188-0.

Nagai, T., Y. Araki and N. Suzuki 2002. Collagen of the skin of ocellate puffer fish (Takifugu rubripes). Food Chemistry 78:173177. DOI: 10.1016/S0308-8146(01)00396-X

Nico, L.G. and R.T. Martin 2009. The South American suckermouth armored catfish, 


\section{H.M.G.K. Herath et al.}

Pterygoplichthys anisitsi (Pisces: Loricaridae), in Texas, with comments on foreign fish introductions in the American Southwest. The Southwestern Naturalist 46(1):98-104. doi:10.2307/3672381

Piez, K.A., M.S. Lewis, G.R. Martin and J. Gross 1961. Subunits of the collagen molecule. Biochemical et Biophysical Acta 53(3):596598.

https://doi.org/10.1016/0006-3002(61)902268.

Rosenblo, J., M. Harsch and S. Jimenez 1973. Hydroxyproline content determines denaturation temperature of chick tendon collagen. Archives of Biochemistry and Biophysics 158:478-484. https://doi.org/10.1016/0003-9861(73)905390 .

Rehn, M., T. Veikkola E. Kukk-valdre, H., Nakamura, M. Ilmonen, C. Lombardo, T. Pihlajaniemi, K, Alitaloand K. Vuori 2001. Interaction of endostain with integrins implicated in angiogenesis. Proceedings of National Academy of Science, USA 98:1024-1029

Saito, M., C. Kiyose, T. Higuchi, N. Uchida and H. Suzuki 2009. Effect of collagen hydrolysates from salmon and trout skins on the lipid profile in rats. Journal of Agricultural and Food Chemistry 57(21):10477-10482.

DOI: $10.1021 / \mathrm{jf} 902355 \mathrm{~m}$

Schmid, F.-X. 2001. Biological Macromolecules: UV visible Spectrophotometry. Encyclopedia of Life Sciences.

https://doi.org/10.1038/npg.els.0003142

Senaratne L.S., P. Park and S. Kim 2006. Isolation and characterization of collagen from brown backed toadfish (Lagocephalus gloveri) skin. Bioresource Technology 97(2):191-197.

Shoulders, M.D. and R.T. Raines 2009. Collagen structure and stability. Annual Review of Biochemistry, 78:929-958.

doi:10.1146/annurev.biochem.77.032207.120 833

Slade, L. and H. Levine 1987. Polymer-chemical properties of gelatin in foods. Advances in Meat Research (USA) 4: 251-266.

Stegemann, H. and K. Stalder 1967. Determination of hydroxyproline. Clinica Chimica Acta 18:267-273.

Sujithra, S., N. Kiruthiga, M. J. Prabhu and R. Kumeresan 2013. Isolation and determination of type I collagen from Tilapia (Oreochromis niloticus) waste. International Journal of Engineering and Technology 5(3):21812185.

Sumanasinghe, H.W. and Amarasinghe, U.S., (2013). Population dynamics of accidentally introduced Amazon sailfin catfish, Pterygoplichthys pardalis (Siluriformes, Loricariidae) in Polgolla reservoir, Sri Lanka. Sri Lanka Journal of Aquatic Sciences 18: 37-45.

Wakida-Kusunoki, A.T., R. Ruiz-Carus and E. Amador-del-Angel, (2007). Amazon sailfin catfish, Pterygoplichthys pardalis (Castelnau, 1855) (Loricariidae), another exotic species established in southeastern Mexico. The Southwestern Naturalist 52(1):141-144. doi. 10.1894/0038-4909

Rui Li, Z. et al., 2013. Isolation and characterization of acid soluble collagens and pepsin soluble collagens from the skin and bone of Spanish mackerel (Scomberomorous niphonius). Food Hydrocolloids 31:103-113. https://doi.org/10.1016/j.foodhyd.2012.10.00 1

Wang, L., X. An, F. Yang, Z. Xin, L. Zhao and $\mathrm{Q}$. $\mathrm{Hu}$ 2008. Isolation and characterisation of collagens from the skin, scale and bone of deep-sea redfish (Sebastes mentella). Food Chemistry 108:616-623.

https://doi.org/10.1016/j.foodchem.2007.11.0 17.

Wijethunga, M.U.I. and U.P.K. Epa 2008. Food resource partitioning of accidentally introduced sucker mouth catfish, Pterygoplichthys multiradiatus with some of the indigenous and intentionally introduced fish species in Sri Lanka. Proceedings of the 10th Annual Scientific Sessions of the Sri Lanka Association for Fisheries and Aquatic Resources, Colombo, Sri Lanka. (Abstract).

Wong, D.W. 1989. Mechanism and theory in food chemistry. Second Edition. Springer. doi. org/10.1007/978-3-319-50766-8

Wu, L.W., C.C. Liu and S.M. Lin (2011). Identification of exotic sailfin catfish species (Pterygoplichthys, Loricariidae) in Taiwan based on morphology and mtDNA sequences. Zoological Studies 50(2):235246.

Zhang, X. M. Ookawa, Y. Tan, K. Ura, S. Adachi and Y. Takagi 2014. Biochemical characterisation and assessment of fibrilforming ability of collagens extracted from Bester sturgeon Huso huso x Acipenser ruthenus. Food Chemistry 160:305-332. 
https://doi.org/10.1016/j.foodchem.2014.03.0

75.

Zhou, T., N. Wang, Y. Xue, T. Ding, X. Liu, X. Mo and J. Sun 2015. Development of biomimetic tilapia collagen nanofibers for skin regeneration through inducing keratinocytes differentiation and collagen synthesis of dermal fibroblasts. ACS Applied Materials and Interfaces 7(5):3253-3262. DOI: $10.1021 / \mathrm{am} 507990 \mathrm{~m}$ 